\title{
Identification and Economic Importance of Banana Phytoparasitic Nematodes in Antioquia Uraba, Colombia
}

\author{
By Eulices Vásquez Tirado \& Eliecer Cabrales Herrera
}

\begin{abstract}
The research work was carried out with the objective of evaluating the populations of phytoparasitic nematodes that affect the banana crop. The research was carried out in the three zones of Antioquia Urabá (North, Central and South), in the rainy season (May-September, 2018). A total of 169 samples were collected from the three zones. Root sampling was done by the technique proposed by Araya and Calvo (2001), the separation of nematodes was done by the sieving and centrifugation method in sucrose solution (Alvarado and López 1985) and its identification was made at the gender level (Maggenti et al. 1987). The following genera were found: Radopholus, Helicotylenchus and Meloidiogyne. In the same way, root damage was found that oscillated 25.2 and $33.4 \%$, without influence on crop production. It was concluded that the populations of dominant nematodes in the Uraba area belong to the genera Radopholus, Helicotylenchus and Meloidiogyne, with high populations, but without significant effect on the yields of the banana crop.
\end{abstract}

Keywords: Nematodes in Urabá, Radopholus sp, Helicotylenchus, Meloidogyne.

\section{Introduction}

Banana is a plant native to Southeast Asia, as a crop estimated to be more than 10,000 years old, whose first traces were found in Papua New Guinea in the vii century before Christ. At present, it is still in the wild in the Philippines, Papua New Guinea and Indonesia and cultivated in tropical and subtropical areas. Natural crosses have produced significant genetic diversity and have allowed the production of no-seedless varieties (UNCTAD 2011).

Banana is the most widely eaten tropical fruit worldwide; it has been established as a technified crop in Colombia as well as in other countries of the world. However, this crop has certain associated pests and diseases that can infer in quality and production, among them are: Sigatoka, Moko, Fusarium, some insects and nematodes. After the necrotic lesions caused by fungi such as Mycosphaderella fijiensis and M. Musicola, the phytoparasitic nematodes (Radopholus similis (Cobb) Thorne), the growth and development of this crop can be threatened, generating losses in production between 20 and 100\% (Guzmán 2011, Seenivasan et al. 2013).

This fruit is the fourth foodstuff of basic necessity in the world; it is consumed raw, or as fried banana, roasted, dry, in juice or in leaflets, alcoholic drinks or flours. It is rich in carbohydrates and contains little fat. It also contains essential vitamins, such as vitamin C, B6, B1, B2 and contains large amounts of potassium

\footnotetext{
*I.A. Group Member of Sustainable Agriculture Research, Colombia.

*Professor, University of Cordoba, Colombia.
} 
and magnesium, which includes it within the group of fruits with great nutritional properties that provide a good amount of carbohydrates, potassium, magnesium, folic acid and fibers. The cultivation of banana requires fertile soil, well drained and frank texture to loam clay; the ideal climate for this fruit is tropical humid, must have a temperature around $18{ }^{\circ} \mathrm{C}$ (Rodríguez and Rojas 2015).

The nematodes are segmented bodies of filiform animals and generally do not present coloration. They have marks in their body of striated form, round bodies of transverse form, varied buccal apparatus, without extremities or other complements. In some cases adult females may take a globose or rounded form (Perry and Moens 2006). They are individuals, whose size varies from 300 to $1,000 \mu \mathrm{m}$ in length and from 15 to $33 \mu \mathrm{m}$ in width, which hinders their visibility (Luc et al. 2005, Perry and Moens 2006). The nematodes have been characterized as being evolved beings, and adapt to different thermal floors, types of soil and water (sweet and salt), and are of great importance to ecosystems (Bongers and Ferry 1999, Baldwin et al. 2004).

In research related to nematodes, regardless of whether they are evaluated as beneficial or harmful, it is essential to perform the identification with high degree of precision, which is very useful to determine the timely management when required (Mai et al. 1996). Identification at the family level, is the category that most researchers and ecologists reach. However, when they have tools, they can reach the species level, which would greatly facilitate the selection of management practices, since with this information, they can know the behavior, evolution and trophic functions (Power 2001).

In banana, there are many nematodes that can affect the development and production of the crop; the literature reports about 146 species distributed in 43 genera of parasitic nematodes or associated to the Mussa species, where migratory endoparasitics (Radopholus similis, Pratylenchus coffeae), ecto-endoparasitic (Helicotylenchus multicinctus and $H$. dihysteria), sedentary endoparasitics (Meloidogyne incognita, M. javanica) and semi-endoparasitic (Rotylenchulus reniformis) are reflected (Martínez et al. 2006).

The genus Pratylenchus is a species of great importance in banana cultivars, especially for the Cavendish variety; its life cycle takes approximately 30 days and for its development requires a temperature of 25 to $30{ }^{\circ} \mathrm{C}$ (Gowen 1994). Likewise, the genera Helicotylenchus and Radopholus are associated to the banana crop, generating small necrotic lesions around the root bark, which under severe conditions can become a problem for the crop (McSorley and Gallaher 1994, Holguín 2018).

The Meloidogyne genus or root-knot nematodes are widely distributed worldwide. This genus, in juvenile state, penetrates the root near or along the radical meristem, invades the endodermis, entering the wake and inducing the formation of multinucleated giant cells derived from the cortical parenchyma or differentiating vascular cells in the central part of the wake (De Waele and Elsen 2002).

Another important genus is the Radopholus or banana borer nematode, which can induce the overturning of the plant. This nematode breaks the cell wall with its stylet and feeds on the cytoplasm of the cells, making cavities that subsequently 
coalesce to form reddish-brown lesions and finally become necrotic by the action of other organisms (Marín et al. 1998).

Nematode management should be done with cultural and preventive practices, such as use of tolerant or antagonistic species, rotation of crops, use of bionematicides based on fungi and bacteria (Rhizobacteria, Bacillus), and in the worst case, use of chemical nematicides, which greatly degrades soil biota (Ferraz et al. 2010, Gowen et al. 2005). The use of fungi, forming mycorrhizal symbioses can also be implemented, which generates a root system that could contribute to the mitigation of the nematode problem in the soils (Bautista et al. 2015).

\section{Aim of the Study}

The main objective of this study was the identification of nematodes of economic importance in the management of banana plantations. The study was carried out in three areas of the Urabá of Antioquia, in the second semester of 2018 .

\section{Materials and Methods}

\section{Location}

The research was carried out in the three zones, in which the Urabá area is divided: North Zone, Central Zone and South Zone. We chose lots that had irrigation, a condition that can favor an ideal moisture regime for the development of phytosanitary diseases; among them, the attack of phytopathogenic nematodes or phytoparasitics. The Urabá is a coastal area on the Caribbean Sea with heights that do not exceed the $20 \mathrm{~m}$, mostly with a slightly flat topography, average temperature of $26.6{ }^{\circ} \mathrm{C}$, average annual rainfall of $2,617 \mathrm{~mm}, 86.2 \%$ relative humidity and a solar brightness of 6.2 hours / days. Its climate is classified as semi-humid warm. The soils are of different texture (clayey-silty, clayey, frank, clayey, silty loam and silty clay loam), well-structured and with a $\mathrm{pH}$ ranging between 5 and 7.5 (Cárdenas et al. 2017).

\section{Selection of Lots}

65 lots were selected in the North Zone, 42 in the Central Zone and 62 in the South Zone. All the lots had an irrigation system and were in productive stage. The area of each plot ranged between 3 and 10 ha cultivars with 12 years of age of establishment within the Canvendis var. Valery and William. 


\section{Root Sampling}

The methodology proposed by Araya and Calvo (2001) was used; roots of five plants in flowering stage (maximum eight days after having emitted the inflorescence or maximum two open bracts) were collected. The collection of the roots was carried out in a trunk of $17 \times 17 \mathrm{~cm}$ and $25 \mathrm{~cm}$ deep, at the base of the pseudostem, oriented in the interval between the mother plant and the son of succession. All the roots were deposited in a plastic bag previously labeled with the identification of the lot and farm of sampling. The sampling was done in three plants per point and all the roots that were found in the soil volume $\left(7225 \mathrm{~cm}^{3} /\right.$ plant) were collected. These samples were taken to CENIBANANO Phytopathology Laboratory for processing.

\section{Processing of Root Samples}

The collected roots were washed with abundant potable water. Then, the functional roots were separated (live roots, turgid, consistent and brown) and nonfunctional (dead roots, flaccid, completely necrotic and blackish). Both roots (functional and non-functional) were weighed using a balance with a precision of $\pm 0.1 \mathrm{~g}$. For the evaluation of the roots the scale proposed by Araya and Calvo (2001) was used. It is illustrated in Table 1.

Table 1. Classification of Ranges for Banana Roots to Weigh

\begin{tabular}{|l|c|c|c|}
\hline & Deficient & Regular & Optimal \\
\hline Total Root & $<70$ & $70-90$ & $>90 \mathrm{~g} / \mathrm{plant}$ \\
\hline Functional Root & $<60$ & $60-75$ & $>75 \mathrm{~g} / \mathrm{plant}$ \\
\hline
\end{tabular}

Source: Araya and Calvo 2001.

\section{Evaluation of Root Damage by Nematodes}

Local scale methodology for evaluation of root damage by nematodes described by Moens et al. (2001) was used; 10 functional roots of the collected sample were taken randomly. Afterwards, they were cut into pieces of $10 \mathrm{~cm}$ in length and finally they were cut longitudinally. Each half was evaluated, measuring the length of the necrotic tissue with a ruler. To calculate the total necrosis of the functional root, the value of the necrotic tissue measured in each half was added, divided by 2 , and this result was divided by 10 and then multiplied by 100 .

$$
\text { WDE DAÑ } O=\frac{r 1+r 2+r 3 \ldots+r 10}{10} \times 100 ; \text { donde } r=\frac{b 1+b 2}{2 \times 10}
$$

r: Root damage ratio

b: Length of edge damage $(\mathrm{cm})$ 


\section{Extraction and Counting of Nematodes}

The methodology of liquefied-sieving adjusted by Alvarado and Lopez (1985) was used. The functional roots were cut into pieces of 0.5 to $1 \mathrm{~cm}$ in length, homogenized and $25 \mathrm{~g}$ were taken, to perform the extraction. These $25 \mathrm{~g}$ of root were deposited in a beaker together with $100 \mathrm{ml}$ of potable water. This process was carried out in a conventional two-speed blender. The first solution was made at low speed (1000 to $1500 \mathrm{rpm}$ ) and the second at high speed (2000 to $2500 \mathrm{rpm}$ ), both for 10 seconds.

Subsequently, all the solutions were added to a set of superimposed sieves of 250, 125 and $25 \mu \mathrm{m}$ opening (No. 60, 120 and 500 respectively). In the 250 micron sieve, the pieces of roots were washed with potable water for two minutes, then in the 125 micron sieve they were washed for one minute and finally the material retained in the 25 micron sieve was deposited in a beaker and completed to $200 \mathrm{ml}$ of potable water for later reading. The suspension was homogenized for $30 \mathrm{~s}$ with a glass stirrer. A $4 \mathrm{ml}$ aliquot was then taken from the center of the beaker and deposited in a reading chamber with $2 \mathrm{ml}$ effective for counting. The number of nematodes was expressed by $100 \mathrm{~g}$ of functional root.

\section{Identification and Quantification of Nematodes}

Processed samples were examined under the 4x objective Microscope and were identified using the taxonomic keys described by Guzmán (2016), published in the manual for the identification of phytoparasitic nematodes (Maggenti et al. 1987).

\section{Bunch Sampling}

At each sampling point within a radius of $30 \mathrm{~m}$, a total of 3 bunches were marked with ages of 3 and 4 weeks after apparition of banana bacotte, with a white ribbon tied at the end of the stem, which contained the information of the sample coordinate and three replicates per point demarcated as R1, R2 and R3. These bunches were harvested at 11 weeks and then the weights in kilograms were taken with the aim of correlating populations of phytoparasitic nematodes with production.

\section{Data Analysis}

The information was tabulated in Excel tables and analyzed with descriptive statistics. There was also proof of abundance, diversity and similarity among the lots of the three evaluated areas, for which the Shannon-Wiener Index was used, which is calculated by formula, in which the number of genera $i$ found between the total number of species in the relevant zone. The diversity index was estimated with the following formulas: 
$p i=\frac{n i}{N} \quad H=-\sum p i * \operatorname{Ln}(p i)$

where:

pi $=$ relative abundance of species $i$.

$\mathrm{ni}=$ number of individuals of the gender $\mathrm{i}$.

$\mathrm{N}=$ number of total individuals.

$\mathrm{H}=$ Shannon-Wiener diversity index.

$\mathrm{Ln}=$ natural logarithm

For interpretation, the relative abundance index will oscillate between 0.0-1.0, being more abundant as it approaches 1.0 , while the diversity index $(\mathrm{H})$ will be interpreted as a positive value with the following scale, <2: low diversity, 2-3: medium diversity, and >3: high diversity. Ggenerally, ecological systems, in general terms, are below 5.0 (Pla 2006, Pla and Matteucci 2001).

\section{Results and Discussion}

\section{Presence of Nematodes}

Three genera of phytoparasitic nematodes were found (Table 2). The North Zone was where the greatest number of nematodes was found, with an average of 70,055 individuals/100 $\mathrm{g}$ of root, while the South Zone had the lowest values of total nematodes, with an average of 16,122 individuals $/ 100 \mathrm{~g}$ of roots. Of the phytoparasitic nematodes found, the genus Helicotylenchus outperformed the other genera in the North and South Zones, but in the Central Zone it was surpassed by the genus Radopholus.

Table 2. Weight of Samples of Banana Roots and Average Number of Nematodes per $100 \mathrm{~g}$ of Roots Collected form South, North and Central of Antioquia Uraba, Colombia (2018)

\begin{tabular}{|l|c|c|c|c|c|c|}
\hline Zone & NS & Rs & Hspp & Mspp & NT & TR \\
\hline South & 62 & $4,632.3$ & $8,903.2$ & $2,587.1$ & $16,122.6$ & 36.9 \\
\hline North & 65 & $27,987.7$ & $42,055.4$ & 12.3 & $70,055.4$ & 58.0 \\
\hline Central & 42 & $25,847.6$ & $23,161.9$ & 100.0 & $49,109.5$ & 48.0 \\
\hline
\end{tabular}

NS: Number of Samples, Rs: Radopholus similis, Hspp: Helicotylenchus spp, Mspp: Meloidogyne spp, NT: Total Nematodes, TR: Total Root (g/plant).

These results are in the ranges reported in the literature. However, the population of Radopholus similis of the South Zone is below the average of 10,000 individuals/100 $\mathrm{g}$ of root reported by Araya and Calvo (2001), enough to cause economic damage to banana plantations. The Central and North Zones exceed the economic damage threshold reported by the above-mentioned authors, whose averages were $25,847.6$ and 27,987.7 individuals/100 $\mathrm{g}$ of roots respectively. 
The populations of the nematodes evaluated, differ; this can be explained because of the biological cycles of each genus. The tendency of Helicotylenchus spp to be found in larger populations may be due to its biological habit, as it is a semi-endoparasitic nematode (Yeates et al. 1993) or ectoparasite which feeds on the nearby tissue of the rhizodermis (Dropkin 1989). As it is shown in Table 2, populations of Helicotylenchus spp were the highest in the three zones evaluated. However, it has not been shown that this nematode migrates through the cortical tissue of banana roots (Siddiqi 1973).

The Population of Meloidogyne spp was relatively low in the three zones of Uraba-Antioquia. However, it is lower than the economic damage threshold for the AAA banana crop which is in accordance with the findings of Araya et al. (1995), who state that populations of this genus are detected in local conditions with few frequencies and population densities.

\section{Abundance and Diversity}

Despite the high populations of phytoparasitic nematodes, the ShannonWeiner Index indicates that there is low diversity $(\mathrm{H}=0.67)$ in the North Zone. Helicotylenchus spp was the dominant species with $60 \%$, followed by Radopholus similis with $39.95 \%$, and the species Meloidogyne spp with 1\%. Similar dynamics were found in the Central Zone - low diversity $(\mathrm{H}=0.69)$. However, in this zone the species Radopholus similis was dominant with $52.7 \%$, followed by Helicotylenchus spp with $47.2 \%$. In the South Zone, there is greater diversity $(\mathrm{H}=$ 0.97 ) and as in the North Zone, the species Helicotylenchus spp was dominant (55.2\%), followed by Radopholus similis (28.7\%). It is noted that in this area, there is a high population of the Meloidogyne species, although its dominance was low $(16 \%)$.

\section{Necrosis Caused by Nematodes}

The average percentages of necrosis in functional roots which were evaluated in each batch and in each zone, showed that the average of necrosis for the North Zone was 25.2\%, while for the Central and South Zones, was $26.6 \%$ and $33.4 \%$, respectively, with a standard deviation that ranged between 9.2 and 10.3 (Table 3). For the analysis of the severity of damage in each batch of each zone, three evaluation ranges were established: less than 20\%, 20 to 50\%, and more than 50\%, indicating low, medium and high, respectively, as illustrated in Table 2. In this table, it can be seen that only in the North Zone there is a low percentage of lots that exceeds the damage threshold and that could be a problem for the management of the banana crop. The great majority of the lots in the three zones has medium infestation (Table 3 ) and it is not economically important. 
Table 3. Percentages of Lots Grown with Bananas Infested by Phytoparasitic Nematodes in the North, Central and South Zones of the Uraba-Antioquia (2018)

\begin{tabular}{|c|c|c|c|c|c|c|}
\hline Ranges & \multicolumn{2}{|c|}{ North Zone } & \multicolumn{2}{|c|}{ Central Zone } & \multicolumn{2}{|c|}{ South Zone } \\
\hline & Lots & $\%$ & Lots & $\%$ & Lots & $\%$ \\
\hline$<20 \%$ & 10 & 37.03 & 5 & 26.32 & 2 & 9.1 \\
\hline $20-50 \%$ & 16 & 59.26 & 14 & 73.68 & 20 & 90.9 \\
\hline$>50 \%$ & 1 & 3.7 & 0 & 0 & 0 & 0 \\
\hline Rank (\%) & \multicolumn{2}{|c|}{$5.9-52.5$} & \multicolumn{2}{|c|}{$8.5-43.0$} & \multicolumn{2}{|c|}{$16.9-47.1$} \\
\hline Average (\%) & \multicolumn{2}{|c|}{25.2} & \multicolumn{2}{|c|}{26.6} & \multicolumn{2}{|c|}{33.4} \\
\hline Standard Deviation & \multicolumn{2}{|c|}{10.3} & \multicolumn{2}{|c|}{10.1} & \multicolumn{2}{|c|}{9.2} \\
\hline
\end{tabular}

\section{Correlations between Nematodes and Yield (Bunch Weight)}

No significant correlations were found between the amount of banana plant parasitic nematodes and their yield (bunch weight). The highest correlation was found in the Central Zone with the species Helicotylechus spp, but no-significant statistics (Table 4). Likewise, in none of the cases, this figure indicates dependence among the intervening factors and that means that the weight of the bunch is not affected by the three types of phytoparasitic nematodes that were found in the studied banana.

The distributions reflected for the yield component with respect to the phytoparasitic populations that were evaluated in the Central Zone, had a high disaggregation of the values with respect to the mean, generating, thus, a low degree of confidence for this variable, demonstrating that the phytoparasitic nematodes do not affect the yield of the banana. Likewise, the same behavior was observed in the populations of Radopholus similis and Meloidogyne spp, but with lower values of correlation in comparison to those released for Helycotilenchus spp. This analysis predicts that other factors may influence the decline in yields, other than the nematode populations.

Very low correlation is presented in the healthy root components for the Central Zone, with the highest numbers, being these of the populations of Radopholus similis and Helicotylenchus spp (Table 4), although these are not sufficient figures to explain the variability of yields bananas crop from the study zone and therefore, are not important economically.

The South Zone, like the other zones studied (North and Central), does not present a correlation for the production variable compared with the populations of nematodes; none of the values obtained in the Pearson correlations explain the variability of banana crop yield. Similar explanations are given for the three zones, in terms of necrosis of the functional roots and the effect of this component on the components of yield (bunch weight), a condition that leads to the prediction that banana crop yields for these three zones studied do not depend on the populations of phytoparasitic nematodes, but on other factors, perhaps those associated with soil problems. For example, physical soil problems (low aeration), salt accumulation, nutritional imbalance, and can be a good subject for other research work. 
Table 4. Pearson Correlation $(R)$ between Populations of Phytoparasitic Nematodes and the Variables Bunch Weight, Root Necrosis (\%) and Total Root $(\mathrm{g} / \mathrm{p})$ of the Three Zones (North, Central and South) of the Antioquia Urabá

\begin{tabular}{|c|c|c|c|c|c|c|c|}
\hline & Hspp & Mspp & NT & $\% \mathrm{RF}$ & $\mathbf{R S}$ & Wbunch & $\%$ Necro \\
\hline \multicolumn{8}{|c|}{ North Zone } \\
\hline Mspp & 0.0253 & & & & & & \\
\hline NT & 0.6898 & 0.1061 & & & & & \\
\hline$\% \mathrm{RF}$ & -0.1042 & 0.0907 & -0.0200 & & & & \\
\hline $\mathbf{R S}$ & -0.1403 & 0.1149 & 0.6201 & 0.0853 & & & \\
\hline Wbunch & -0.1092 & -0.1411 & -0.1342 & -0.0732 & -0.0648 & & \\
\hline \% Necro & -0.0396 & -0.0019 & 0.1974 & 0.0445 & 0.3064 & -0.1901 & \\
\hline WRT & 0.1434 & 0.0252 & 0.1876 & -0.0301 & 0.1012 & 0.0272 & 0.1368 \\
\hline \multicolumn{8}{|c|}{ Central Zone } \\
\hline Mspp & 0.3172 & & & & & & \\
\hline NT & 0.6959 & 0.1055 & & & & & \\
\hline$\% \mathrm{RF}$ & -0.4146 & -0.1243 & -0.3074 & & & & \\
\hline $\mathbf{R S}$ & 0.3472 & -0.0555 & 0.9150 & -0.1686 & & & \\
\hline Wbunch & -0.3336 & -0.1007 & -0.3926 & 0.2260 & -0.3247 & & \\
\hline$\%$ Necro & 0.2948 & 0.0226 & 0.2525 & -0.0838 & 0.1653 & -0.0240 & \\
\hline WRT & 0.1081 & 0.2027 & 0.0894 & -0.1426 & 0.0530 & 0.1926 & 0.1595 \\
\hline \multicolumn{8}{|c|}{ South Zone } \\
\hline Mspp & -0.0745 & & & & & & \\
\hline NT & 0.6789 & 0.4096 & & & & & \\
\hline$\% \mathrm{RF}$ & -0.5245 & 0.1099 & -0.3900 & & & & \\
\hline $\mathbf{R S}$ & 0.1396 & -0.0806 & 0.6265 & -0.1935 & & & \\
\hline Wbunch & -0.1988 & -0.0098 & -0.1621 & 0.1274 & -0.0533 & & \\
\hline \% Necro & -0.1431 & -0.0414 & -0.1685 & 0.0126 & -0.0981 & 0.0932 & \\
\hline WRT & -0.0655 & -0.1084 & -0.0158 & 0.0611 & 0.1091 & 0.1384 & -0.1845 \\
\hline
\end{tabular}

Mspp: Meloidogyne spp, Hspp: Helicotylenchus spp, RS: Radopholus similis, NT: Nematodes Total, \%RNF: \% Root Functional, WRT: Weight Total Root, WBunch: Weight Bunch.

\section{Production of Total Roots of Banana}

As it is shown in Table 5, the three zones, in general, presented values below $70 \mathrm{~g} / \mathrm{plant}$, which would be classified according to Araya and Calvo (2001), lots with a deficient root system; only for the North Zone a $11.1 \%$ of the lots evaluated are root systems in the regular range, $3.7 \%$ are root systems in the optimal range and finally $85 \%$ are in the deficient range. These differences can be explained by the intrinsic conditions of the sampling site (soil type and nutrition, among others).

Table 5. Total Root Production of Banana Plants from Three Zones (North, Central and South) of Urabá Antioquia

\begin{tabular}{|l|c|c|c|}
\hline Ranges & North Zone & Central Zone & South Zone \\
\hline Range (g/plant) & $36.0-95.3$ & $25.7-65.7$ & $22.3-50.6$ \\
\hline Average (g/plant) & 58.9 & 47.2 & 36.7 \\
\hline Standard Deviation & 14.4 & 10.5 & 9.0 \\
\hline
\end{tabular}


For the Central and South Zones, all the lots (100\%) evaluated are in the deficient range, with values lower than $70 \mathrm{~g} /$ plant, having averages of total root weight per plant $47.2 \mathrm{~g}$ and $36.7 \mathrm{~g}$, respectively. These low values predict that there are soil problems, possibly because of the long time that these lots have been exploited (more than 30 years) For example, they may be problems of soil aeration.

\section{Conclusions}

From the research that has been done the following conclusions can be drawn. Firstly, the lots under study belonging to the three zones of Urabá Antioqueño have low root production, perhaps due to abiotic rather than biotic problems. Secondly, the development of the biological cycle of each genus of phytoparasitic nematodes in banana cultivation can influence the final populations registered in each evaluation. Thirdly, Averages of root necrosis are not enough to affect yield components (bunch weight) in the three zones studied (North, Central and South) and finally, the Urabá banana zone has the three genera of phytoparasitic nematodes of the greatest care in the management of banana crops. However, their populations are not important economically.

\section{References}

Alvarado M, López R (1985) Extracción de algunos nematodos fitoparásitos mediante modificaciones de las técnicas de centrifugación flotación y embudo de Bareman modificado. [Extraction of some phytoparasite nematodes by modifications of the modified Bareman flotation and funnel centrifugation techniques]. Agronomía Costarricense 9(2): 175-180.

Araya M, Calvo C (2001) Cantidad de raíces de banano en los diez cantones productores de Costa Rica. [Number of banana roots in the ten producing cantons of Costa Rica]. Corbana 27(54): 47-64.

Araya M, Centeno M, Carrillo W (1995) Densidades poblacionales y frecuencia de los nematodos parásitos del banano (Musa AAA) en nueve cantones de Costa Rica. [Population densities and frequency of banana parasitic nematodes (Musa AAA) in nine cantons of Costa Rica]. Corbana 20(43): 6-11.

Baldwin J, Nadler S, Adams B (2004) Evolutions of plants parasitism among nematodes. Annual Review of Phytopathology 42(1): 83-105.

Bautista M, Bolaños B, Massae Asakawa N, Villegas E (2015) Respuesta de fitonematodos de plátano Musa AAB Simmonds a estrategias de manejo integrado del suelo y nutrición. [Response of Musa AAB Simmonds banana phytonymatodes to integrated soil management and nutrition strategies]. Revista Luna Azul 40(Jun): 69-84.

Bongers T, Ferris H (1999) Nematodes community structure as a bioindicator in enviromental monitoring. Trends in Ecology \& Evolution 14(6): 224-228.

Cárdenas J, Zapata S, Sánchez J (2017) Análisis productivo de plátano en alta densidad y su relación con la precipitación en Urabá. [Productive analysis of banana in high density and its relationship with precipitation in Urabá]. Revista Politécnica 13(24): 27-35. 
De Waele D, Elsen A (2002) Migratory endoparasites: Pratylenchus and Radopholus species. [Migratory endoparasites: Pratylenchus and Radopholus species]. In JL Starr, R Cook, J Bridge (Eds.), Plant Resistence to Parasitic Nematodes. CAB International.

Dropkin V (1989) Introduction to Plant Nematology. $2^{\text {nd }}$ Edition. New York: John Wiley \& Sons, 304.

Ferraz S, Freitas LG, Lopes EA, Dias-Arieira CR (2010) Manejo sustentável de fitonematoides. [Sustainability of phytonematoids]. Viçosa: Editora UFV, 306.

Gowen S (1994) Burrowing nematode root rot (blackhead toppling disease). In RC Plates, GA Zimmer, W Nishijima, K Rohrbach, H Ohr (Eds.), Compendium of Tropical Fruit Diseases, 21. St. Paul, MN: American Phytopathological Society.

Gowen S, Quénéhervé P, Fogain, R (2005) Nematodes parasites of bananas and plantains. In M Luc, RA Sikora, J Bridge (Eds.), Plant Parasitic Nematodes in Subtropical and Tropical Agriculture, 611-643. $2^{\text {nd }}$ Edition. Oxfordshire, UK: CABI Publishing.

Guzmán Ó (2011) El nematodo barrenador (Radopholus Similis [Cobb] Thorne) del banano y plátano. [The borer nematode (Radopholus Similis [Cobb] Thorne) of banana and plantain]. Luna Azul Ucaldas 33: 1-17.

Guzmán Ó (2016) Manual para la identificación de nematodos fitoparásitos. [Manual for the identification of phytoparasite nematodes]. Manizales: 23-134.

Holguín A (2018) Nematodos parásitos asociados al cultivo de banano (musa spp.) en el distrito de la matanza, valle del alto piura. [Parasitic nematodes associated with the cultivation of bananas (musa spp.) In the district of La Matanza, Alto Piura Valley]. Undergraduate Thesis. Perú: Universidad Nacional de Piura.

Luc M, Sikara RA, Bridge DJ (2005) Plant parasitic Nematodes in subtropical and tropical agricultura. $2^{\text {nd }}$ Edition. Egham, UK: CABI Bioscience.

Maggenti A, Luc M, Raski D, Fortuner R, Geraert E (1987) A reappraisal of Tylenchina (Nemata). 2 Clasifications of the suborder Tylenchina (Nemata: Dipoglasteria). Revue Nematology 10(2): 135-142.

Mai W, Mullin P, Lyon H (1996) Plant parasitic nematodes: a pictorial key to genera. $5^{\text {th }}$ Edition. Ithaca, NY: Cornell University press.

Marín DH, Sutton T, Barker K (1998) Dissemination of bananas in Latin America and the Caribbean and its relationship to the occurrence of Radopholus similis. Plant Disease 82(9): 964-974.

Martínez H, Pena Y, Espinal C (2006) La cadena de plátano en Colombia: una mirada global de su estructura y dinámica 1991-2005. [The banana chain in Colombia: a global view of its structure and dynamics 1991-2005]. Working Document No. 102. Bogotá, Colombia: Ministry of Agriculture and Rural Development. Retrieved from https://bit.ly/2Fy2QaO. [Accessed: November 24, 2018].

McSorley R, Gallaher RN (1994) Effect of yard waste compost on plant-parasitic nematode densities in vegetable crops. Supplement to the Journal of Nematology 27(4S): 545549.

Moens T, Araya M, De Waele D (2001) Correlaciones entre el número de nematodos y el daño de las raíces en banano (Musa AAA) bajo condiciones comerciales. [Correlations between the number of nematodes and root damage in banana (Musa AAA) under commercial conditions]. Nematropica 31(01): 55-65.

Perry R, Moens M (2006) (Eds.) Plant nematology. London: CAN International.

Pla L (2006) Biodiversidad: Inferencia basada en el índice de Shannon y la riqueza. [Biodiversity: Inference based on the Shannon index and wealth]. Interciencia 31(8): 583-591.

Pla L, Matteucci S (2001) Intervalos de confianza bootstrap del índice de biodiversidad de Shannon. [Bootstrap confidence intervals from the Shannon biodiversity index]. Revista Facultad de Agronomía (LUZ) 18(3): 222-234. 
Power T (2001) Nematodes workshop: recognizing families of dorylaimida. Lincoln: Department of Plant Pathology, University of Nebraska.

Rodríguez, M., and Rojas, M. 2015. Análisis de la producción y comercialización del banano, su aceptación y evolución frente al Tratado de Libre Comercio con la Unión Europea. [Analysis of the production and marketing of bananas, their acceptance and evolution against the Free Trade Agreement with the European Union]. Undergraduate Thesis. Bogotá, Colombia: Universidad del Rosario.

Seenivasan N, Manoranjitham S, Auxilia J, Soorianathasundaram K (2013) Management of nematodes in banana through bio-rationale approaches. Pest Management in Horticultural Ecosystems 19(1): 38-44.

Siddiqi M (1973) Helicotylenchus multicinctus. C.I.H. Descriptions of plant-parasitic nematodes. No 23. England: Commonwealth Institute of Helminthology, 3-160.

UNCTAD (2011) Banano. [Banana]. Conferencia de las Naciones Unidas Sobre Comercio y Desarrollo Banana. Retrieved from https://bit.ly/2NaDqnW. New York y Ginebra: Nations Unies CNUCED.

Yeates G, Bongers T, De Goede R, Freckman D, Georgieva S (1993) Feeding habits in soil nematodes families and genera-an outline for soil ecologists. Journal of Nematology 25(3): 315-331. 